\title{
The effect of obesity on the outcome of total knee arthroplasties in arthritic patients
}

\author{
Philip Drohat $^{1}$, Dr. Melissa Kiehl ${ }^{1}$, Dr. Charles F. Mess ${ }^{1}$
}

The purpose of an arthritic patient receiving a total knee arthroplasty is to relinquish them of their pain and return them to a normal level of functionality. In obese patients, it is unclear if their increased body mass impedes their recovery process. Since obesity is an epidemic on the rise in the United States, it is of great importance to determine whether it is worth it for obese patients to undergo a total knee arthroplasty or if they need to take any precautions. While there is already a great deal of research on this topic, it is incredibly unclear and does not draw any conclusions. This study is a meta-analysis of four different studies looking at how obesity affects the outcome of a total knee replacement. Each study was looked at for its purpose, methods, perioperative and immediate results, implant survival results, functionality results, discussion, limitations, and conclusions. Within these four studies, there were instances in which they agreed; however, there were also instances in which they directly contradicted each other. The conclusions of all four studies were similar and advised that obese patients should be counseled on their risk. One interesting point was made that perhaps these studies need to be looking at total body weight instead of body mass index because one is absolutely whole the other in relative. The data from the meta-analysis could not support the hypothesis since there was no general consensus, but it does provide novel insight into this field of study that could change future experiments to provide meaningful results.

Keywords: Total knee arthroplasty; outcome; arthritis; obesity

One in five Americans are affected by arthritis; however, when it comes to obese Americans, those numbers change to one in three. Arthritis is the deterioration of cartilage in a joint, and it can take many forms based on what caused the arthritis, but the most common is osteoarthritis, which is caused by a genetic predisposition and overuse. The deterioration of cartilage can become extremely painful, and at that point, the only correction is surgery. For advanced knee arthritis, a total knee arthroplasty is usually the best corrective surgery. The surgeon removes the distal end of the femur and proximal end of the tibia and then mounts a prosthesis on each. Between these prostheses is an articulating surface, in many cases made of polyethylene, and altogether this composes the implant. Unfortunately, doctors are skeptical when it comes to performing this surgery on patients with high body mass index (BMI). Two groups, in particular, are red flags: obese patients (BMI between $30 \mathrm{~kg} / \mathrm{m}^{2}$ and $40 \mathrm{~kg} / \mathrm{m}^{2}$ ) and morbidly obese patients (BMI above $40 \mathrm{~kg} / \mathrm{m}^{2}$ With obesity on the rise, it is crucial to determine how the body mass index of the patients affects the recovery of their total knee arthroplasties. This paper will contrast the surgical process of a total knee arthroplasty between non-obese and obese patients, determine the duration of the total knee implants in non-obese, obese, and morbidly obese patients, and compare the function gained from the total knee arthroplasty surgery between the non-obese, obese, and morbidly obese patients. This paper will attempt to evaluate the effects of the body mass index of an arthritic patient undergoing a total knee arthroplasty on their recovery.

\section{Review of Literature}

Patients of varying body mass indexes undergoing a total knee arthroplasty may have a dissimilar surgical process. The most obvious difference stems from the fact that it is harder to identify the human anatomy in an obese or morbidly obese patient (Salih, S. et al., 2013). The harder it is for the surgeon to operate, the longer the surgery will take, exposing the obese and morbidly obese patients to a greater risk of infection (C. Mess, personal communication, January 3,2018). Other issues and concerns are present when performing this surgery on an obese or morbidly obese patient, such as a higher risk for malalignment of the prosthesis (Salih, S. et al., 2013). Vaishya, R. et al. (2016) found that complications rates were higher for morbidly obese patients in seven out of every eight studies they looked at. Before an obese or a morbidly obese patient has begun their recovery process, there is a preestablished risk that they must face. There are many smaller risks of surgery that can complicate the recovery, drastically abridging the functional period of their implant. Inherent risks of surgery are always a concern to the surgeon, but they are even more so with obese patients.

Obese and morbidly obese patients face the stated risk that comes with some implants. In a study by Craik, J.D. et al. (2016), $40 \%$ of the total knee implants they looked listed obesity as a contraindication or a reason to recommend against the use of their implant. Obese and morbidly obese patients have a potential roadblock before even getting the surgery. Some of these implants are not designed for obese patients, and the producers of these products believe it could be dangerous for them to even use them, because of the elevated risks associated with installation and maintenance. However, a majority of the implant designs did not list obesity as a contraindication against use. In addition to risks purely associated with obesity, obese patients have to be cautious of the inherent risks, such as the malalignment or other complications. Even if prosthetic manufacturers were making implants that were designed for obese patients, they still have another challenge facing them. Some surgeons do not feel comfortable operating on this subset of the population and will refuse surgery (B. Chase, personal communication, December 17, 2017). One reason being is that surgeons may not have the experience necessary to feel comfortable operating on obese and morbidly obese patients;

\footnotetext{
${ }^{1}$ Mount Hebron High School, Ellicott City, MD, 21042

Correspondence: philipdrohat@gmail.com
} 
however, obesity is on the rise, and the demand for total knee arthroplasties by obese and morbidly obese patients will also be increasing (L. Esposito, personal communication, December 20, 2017). Surgeons are becoming more comfortable operating on a wider range of body mass indexes. As of now, it appears that an obese or morbidly obese patient could find a surgeon willing to operate on them, but it may take some tough searching because most surgeons would request weight loss prior to surgery. Weight loss is more difficult because of the fact that these patients have painful joints that limit physical exercise, which is needed for sustained weight loss. Finding a surgeon can be difficult in the already risk-laden road that the obese and morbidly obese patients are on, but there is still more trouble to be found.

Immediately after surgery, the obese and morbidly obese patients are faced with two more tolls. Since the surgery takes longer in obese and morbidly obese patients, there are more supplies used, and this can amount to high costs for the morbidly obese patients, who on average have a 7\% higher hospital bill (Rodriguez-Merchan, E.C., 2014). This may not appear to be a substantial increase, but when the surgery costs around $\$ 50,000$, the morbidly obese patients could end up paying thousands of dollars extra. Although this would not affect the morbidly obese patient's recovery, it may deter them away from surgery. Obese and morbidly obese patients also have larger incisions and incur more extensive, deep dissection of the knee during surgery (C. Mess, personal communication, January 3, 2018). This can make the surgery more painful for obese and morbidly obese patients; however, if an obese or morbidly obese patient finds a surgeon that will operate on them, and accepts the inherent risks of surgery, a slightly higher cost, and more pain appear insignificant. The non-obese patient has a relatively easier experience with surgery and less risk. Whereas an obese or morbidly obese patient is faced with more challenges and relatively higher risk than non-obese patients, which could seriously alter the outcome of surgery.

The recovery process is similar to the surgical process in that it differs for people of varying body mass indexes. One side of the recovery that is strongly influenced by body mass index is the lifespan of the implant. Total knee implants have an average lifespan of 10 to 15 years; however, many factors play into altering this number (Frey, R., 2015). Salih, S. et al. (2013) found that after seven years, obese patients had the highest implant failure rates, but the morbidly obese patients had higher survival rates than obese patients, while both groups had higher failure rates than non-obese patients. Morbidly obese patients were not the worst off because they were typically less active than the obese patients, so they had not worn out their implant as quickly. Foran, J.R., et al. (2004) were able to determine that the decreased survival rates in the obese patients became apparent between 60- and 80-months succeeding surgery. This is not the case for all obese and morbidly obese patients; however, the five-year period is when the recovery process begins to diverge for the obese patients. A contradictory study conducted by Vaishya, R. et al. (2016) found that at 14 years, the implant survival rates for non-obese and obese patients were $49 \%$ and $71 \%$ respectively. While this does appear to bode well for the morbidly obese patients, this is only caused by the dramatic differences in exercise levels between the two groups, which then leads to the fact that the morbidly obese patients have lower functionality scores along with the greater pain, and even decreased quality of life. Also, the non-obese patient's survival rate seems surprisingly low in those statistics, but 14 years is nearing the end of the average life expectancy of the implant anyway, so the low implant survival rate at this time period should be expected.

The reasons for obese patients experiencing lower survival rates in their implants can be attributed to many factors. Their higher weight leads to higher forces at the interface between the bone and the implant, which increases the risk of the implant loosening (Wang, C., et al., 2017). If the implant is loosened to the point where it cannot function correctly, a revision surgery is required, meaning that the implant has then prematurely failed. Stevens-Lapsley, J.E., et al. (2009) were able to determine that, "For every pound of weight loss in patients with osteoarthritis, there is a four-fold reduction in the load exerted on the knee with daily activities." This highlights the magnitude at which obesity puts stress on the knee. As a patient's body mass index increases, the stress applied across their knee will increase exponentially, which would then make them more susceptible to loosening and premature implant failure. This statistic also emphasizes how impactful weight loss can be, especially in a patient planning on or who has just received a total knee arthroplasty. Another reason that obesity can alter the lifespan of the implant is that after a total knee arthroplasty, obesity will transfer stress through the total knee prosthetic to surrounding bone (Amin, A.K., et al., 2006). In this case, the higher the body weight, the greater the amount of stress being applied to the articulating bones of the knee, and a greater chance of implant failure. Not only is more stress and force being applied to the implant in obese and morbidly obese patients, but they are also placing their implant under unnecessary stress. Wang, C., et al. (2017) noted that obese and morbidly obese patients have shorter steps, so they require more steps to cover the same distance than a non-obese patient would, creating an increase in contact pressure that wears the implant. Although taking more steps while walking would not drastically alter the survival of the implant, this holds true for any weight-bearing activity performed by an obese or morbidly obese patient. These two groups are putting unnecessary wear on their implant with every step they take, and it could be reduced simply by weight loss.

Obesity also causes yet another issue surrounding the duration of the implant. Amin, A.K., et al. (2006) noted that obese patients tend to have early onset symptoms of arthritis, so they required knee replacement surgery sooner. Regardless of their obesity, the implants only last around 15 years in healthy people, so obese patients will end up needing a revision sooner, or at a younger age, than non-obese patients. While a non-obese patient might not require a total knee arthroplasty until an old age and only have one implant in their lifetime, an obese or morbidly obese patient may experience symptoms sooner and require the surgery at a younger age. This increases the probability that they will outlive their prosthetic and a revision surgery may be necessary for them later in life. These factors all contribute to the decreased implant lifespan commonly found in obese patients postoperatively, which hinders the recovery of their total knee arthroplasty.

The other major aspect of recovery is the function that these patients are regaining from the surgery. In this aspect, the body mass index still has an effect on the recovery, but not as drastically as it does with implant survivorship. Rodriguez-Merchan, E.C. (2014) found that general obesity does not have an effect on functionality after surgery; however, once the morbidly obese range is entered, postoperative functionality scores begin to decline. More specifically, only after BMI surpasses $40 \mathrm{~kg} / \mathrm{m}^{2}$, the cutoff 
for morbid obesity, will reduced functionality become present (Stevens-Lapsley, J.E., et al., 2009). Functionality is gauged by a knee score, which is taken prior to and after surgery, and then the two scores are compared to detect improvement. That being said, the obese patients are not experiencing any differences from the non-obese patients. Stevens-Lapsley, J.E., et al. (2009) noticed that obese patients did have lower functionality scores compared to the non-obese patients, but the differences between their preoperative and postoperative scores were close to identical. The equivalent mean improvement between the obese and non-obese groups resulted in functionality scores that did not vary remarkably in the short term (Vaishya, R. et al., 2016). Although the obese patients had the same change in knee scores, they had lower scores to begin with because they are naturally less active than nonobese patients. As body mass index increases, the patient will be naturally less active, but their knee scores will only show significantly less improvement when they become morbidly obese. Once a patient is in that condition, they have so many other problems that getting a total knee replacement would not dramatically improve their functionality. It is for this same reason that the morbidly obese patient's implants tend to last longer than the obese patients because they are not as active. A trade up is presented; while on one hand, a non-active lifestyle leads to less functionality, it could possibly lead to a longer implant lifespan, and on the other hand, an active lifestyle could lead to a shortened implant lifespan but higher knee functionality.

A final part of functionality that is not so clear is the patient's satisfaction with their function. Craik, J.D. et al. (2016) found that obese and morbidly obese patients reported poorer quality of life and satisfaction than non-obese patients. There are many possible reasons for these lower satisfaction scores, but Salih, S. et al. (2013) reported that many obese and morbidly obese patients attributed it either to their obesity directly or a secondary obesity issue. If obesity is the cause of the postoperative lower satisfaction or quality of life, the surgery could still help to correct that. Preoperatively, it is challenging for a patient to lose weight because their symptoms of arthritis make exercise painful; however, if the total knee arthroplasty corrects these issues, it is then easier for the patient to comfortably lose weight and have a higher satisfaction with their implant. Unfortunately, if a heavier patient were to exercise at an increased rate, they would exert more pressure across their implant more frequently, and likely cause it to fail at a sooner time than it would have otherwise. Many factors can contribute to the recovery of a total knee arthroplasty in an arthritic patient, and at high body mass indexes, the lines of recovery are blurred and must be more closely examined to determine if the surgery is worthwhile for the patient.

Whether body mass index does or does not affect the recovery of total knee arthroplasties in arthritic patients, obesity is becoming more common, so surgeons need to find methods to make total knee arthroplasties more similar between non-obese, obese, and morbidly obese individuals. Prosthetics must also be reconstructed to be more accommodating to its heavier users because this is a rapidly growing group. A larger range of body mass indexes should be supported by these implants for equal amounts of time. The surgical process is already longer, more complicated, and more expensive for some of these patients. Obese and morbidly obese patients should not need to get more than one surgery because their first implant has failed. Most importantly, doctors need to stress the importance of weight loss to their patients prior to and after surgery in order to benefit their postoperative functionality and satisfaction, as well as to ensure they are not unnecessarily stressing their implant.

\section{Results}

The research questions was, does the body mass index of an arthritic patient undergoing a total knee arthroplasty have an impact on their recovery. The hypothesis was that obesity would have a negative effect on the recovery of total knee arthroplasties in arthritic patients. The thorough analysis of each of the four studies is found in Table 1. Recovery of surgery was determined based on functionality gained from surgery and

Table 1

Meta-analysis of Four Total Knee Arthroplasty Outcome Studies

\begin{tabular}{|c|c|c|c|c|}
\hline & $\begin{array}{l}\text { Obesity may impair the } \\
\text { early outcome of total } \\
\text { knee arthroplasty } \\
\text { (1) }\end{array}$ & $\begin{array}{l}\text { Body mass index as a } \\
\text { predictor of outcome in } \\
\text { total knee replacement } \\
\text { (2) }\end{array}$ & $\begin{array}{l}\text { Total knee replacements } \\
\text { in morbidly obese } \\
\text { patients: } \\
\text { Results of a prospective, } \\
\text { matched study } \\
\text { (3) }\end{array}$ & $\begin{array}{l}\text { The impact of pre- } \\
\text { operative obesity in } \\
\text { weight change and } \\
\text { outcome in total knee } \\
\text { replacements } \\
\text { (4) }\end{array}$ \\
\hline $\begin{array}{l}\text { Purpose of } \\
\text { Study }\end{array}$ & $\begin{array}{l}\text { To examine the effects of } \\
\text { obesity on short-term } \\
\text { outcome of total knee } \\
\text { replacements, } \\
\text { specifically } \\
\text { postoperative function } \\
\text { and complications. }\end{array}$ & $\begin{array}{l}\text { To assess the effect of } \\
\text { body mass index as a } \\
\text { predictor of outcome and } \\
\text { survival in total knee } \\
\text { replacements. }\end{array}$ & $\begin{array}{l}\text { To assess the influence of } \\
\text { morbid obesity on the } \\
\text { outcome after TKR by } \\
\text { comparing an obese } \\
\text { group to a matched non- } \\
\text { obese group. }\end{array}$ & $\begin{array}{l}\text { 1) To establish the rate } \\
\text { of clinically significant } \\
\text { change in patients } 12 \\
\text { months after primary } \\
\text { TKR 2) to compare the } \\
\text { characteristics of } \\
\text { patients who lost or } \\
\text { gained weight after } \\
\text { primary TKR with } \\
\text { those who did not } 3 \text { ) to } \\
\text { compare the clinical } \\
\text { and functional } \\
\text { outcome between }\end{array}$ \\
\hline
\end{tabular}




\begin{tabular}{|c|c|c|c|c|}
\hline & & & & $\begin{array}{l}\text { obese and non-obese } \\
\text { patients after TKR }\end{array}$ \\
\hline Methods & $\begin{array}{l}\text { Looked at } 100 \text { primary } \\
\text { unilateral total knee } \\
\text { replacements. Patients } \\
\text { were evaluated two } \\
\text { weeks prior to surgery } \\
\text { and three months after } \\
\text { surgery. The length of } \\
\text { the incision and range of } \\
\text { motion was measured, } \\
\text { and the level of pain and } \\
\text { patients satisfaction were } \\
\text { also documented. } \\
\text { Walking ability was } \\
\text { measured by the timed } \\
\text { Get-Up-and-Go test. } \\
\text { Patients were divided } \\
\text { into Group } 1 \text { (n=48) with } \\
\text { BMI<30 and Group } 2 \\
\text { (n=52) with BMI } \geq 30 \text {. }\end{array}$ & 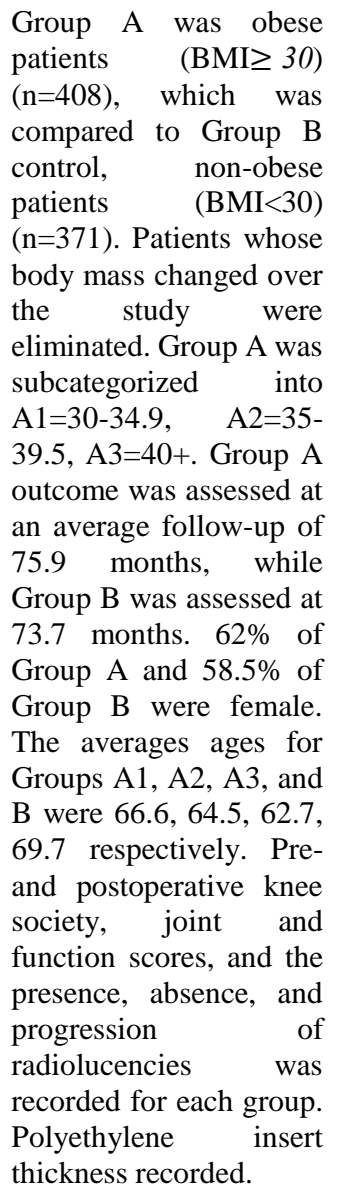 & $\begin{array}{l}\text { Patients were followed up } \\
\text { at } 6,18,36 \text {, and } 60 \\
\text { months postoperatively. } \\
41 \text { TKRs were performed } \\
\text { in } 38 \text { morbidly obese } \\
\text { patients that were } \\
\text { matched with a control } \\
\text { group of } 41 \text { TKRs in } 38 \\
\text { non-obese patients. Two } \\
\text { groups were matched for } \\
\text { age, gender, diagnosis, } \\
\text { prosthesis type, laterality, } \\
\text { and preoperative knee } \\
\text { score (KSS). The patella } \\
\text { was not resurfaced and } \\
\text { the posterior cruciate } \\
\text { ligament was preserved } \\
\text { when possible. } \\
\text { Postoperative KSS was } \\
\text { analyzed. Presence of } \\
\text { radiolucent lines and } \\
\text { malalignment was } \\
\text { detected radiologically. } \\
\text { Five-year survivorship } \\
\text { was determined using just } \\
\text { revision as an endpoint } \\
\text { and then again with } \\
\text { revision or pain as the } \\
\text { endpoint. Statistical } \\
\text { significance was defined } \\
\text { by p } 05 \text {. }\end{array}$ & $\begin{array}{l}\text { Preoperative data } \\
\text { included age, gender, } \\
\text { type of surgery, height } \\
\text { and weight, } \\
\text { comorbidities, } \\
\text { functionality } \\
\text { assessment, and } \\
\text { quality of life (QoL), } \\
\text { all taken at pre-op } \\
\text { exam } 4 \text { weeks in } \\
\text { advance. Information } \\
\text { was again collected at } \\
\text { the } 12 \text { month follow } \\
\text { up. The functional } \\
\text { knee assessment used } \\
\text { the International Knee } \\
\text { Score (IKS). A change } \\
\text { of } 5 \% \text { from the } \\
\text { patient's pre-op body } \\
\text { was considered } \\
\text { significant. } 529 \\
\text { patients were recruited } \\
\text { to be in this study, of } \\
\text { those, } 365 \text { were } \\
\text { women and } 164 \text { were } \\
\text { men. There was a } \\
\text { median age of } 71 \text { and } \\
\text { median BMI of } 31.3 \text {. } \\
211 \text { ( } 40 \% \text { ) were non- } \\
\text { obese, } 261 \text { (49\%) were } \\
\text { obese, and } 57 \text { ( } 11 \% \text { ) } \\
\text { were morbidly obese. }\end{array}$ \\
\hline $\begin{array}{l}\text { Perioperative } \\
\text { and Immediate } \\
\text { Results }\end{array}$ & $\begin{array}{l}\text { No statistical } \\
\text { significance between } \\
\text { age, \# of chronic disease, } \\
\text { medication, or smoking. } \\
\text { Obese patients had } \\
\text { longer skin incisions } \\
\text { ( } \mathrm{p}=.003) \text { and had more } \\
\text { postoperative pain } \\
\text { ( } \mathrm{p}=.013) \text {. Five } \\
\text { postoperative } \\
\text { complications in group } 2 \\
\text { and none in group } 1 \\
\text { ( } \mathrm{p}=.028) \text {. Group } 2 \text { had } \\
\text { significantly higher } \\
\text { technical errors }(\mathrm{p}=.007) \text {. } \\
\text { BMI correlated with } \\
\text { higher pain }(\mathrm{p}=.018) \text { and } \\
\text { longer incision }(\mathrm{p}=.015) \text {. }\end{array}$ & $\begin{array}{l}\text { Trend in early age for } \\
\text { surgery as BMI } \\
\text { increases. Obese group } \\
\text { had a statistically higher } \\
\text { radiographic rate } \\
\text { (p=.0016). Additional } \\
1.2 \% \text { of obese group had } \\
\text { radiographic evidence of } \\
\text { tibial component wear } \\
\text { based on the } \\
\text { polyethylene thickness, } \\
\text { statistically } \\
\text { insignificant. }\end{array}$ & $\begin{array}{l}\text { No significant differences } \\
\text { between the morbidly } \\
\text { obese and nonobese } \\
\text { group for preoperative } \\
\text { matched variables. Mean } \\
\text { follow-up time for } \\
\text { morbidly obese was } 38.5 \\
\text { months and for non-obese } \\
\text { was } 44 \text { months; not } \\
\text { statistically significant } \\
\text { (p=.3). Significantly } \\
\text { higher rate of radiolucent } \\
\text { lines around implants in } \\
\text { morbidly obese patients } \\
\text { compared to non-obese, } \\
29 \% \text { and } 7 \% \text { respectively } \\
\text { (p=.02). Overall rate of } \\
\text { complications higher in } \\
\text { morbidly obese group } \\
\text { compared to non-obese } \\
\text { group, 32\% to 0\% } \\
\text { respectively (p=.001). }\end{array}$ & $\begin{array}{l}\text { The obese groups were } \\
\text { more often female, } \\
\text { were significantly } \\
\text { younger, and had } \\
\text { higher incidence of } \\
\text { cardiovascular } \\
\text { comorbidities and } \\
\text { diabetes than the non- } \\
\text { obese group. } \\
\text { Complications } \\
\text { occurred in } 35.1 \% \text { of } \\
\text { morbidly obese } \\
\text { patients, } 22.1 \% \text { of } \\
\text { obese patients, and } \\
14.2 \% \text { of non-obese } \\
\text { patients (p=.001). The } \\
\text { OR for the risk of } \\
\text { complication was } \\
1.084 \text { for every unit } \\
\text { increase in BMI. }\end{array}$ \\
\hline Functionality & Obese patients range of & Postoperative & In both groups, the mean & difference \\
\hline
\end{tabular}




\begin{tabular}{|c|c|c|c|c|}
\hline & $\begin{array}{l}\text { postoperative motion } \\
\text { was worse }(\mathrm{p}=.001) \text {. No } \\
\text { difference between the } \\
\text { groups Get-Up-and-Go } \\
\text { test. The walking } \\
\text { distance in group } 2 \text { was } \\
\text { slightly shorter. Group } 1 \\
\text { had a clear but not } \\
\text { significant increase in } \\
\text { range of motion ( } 7.3 \%) \\
\text { ( }=.055) \text {, while group } 2 \\
\text { had no change in range of } \\
\text { motion }(1.0 \%) \text { BMI had } \\
\text { a negative correlation } \\
\text { with range of motion } \\
(\mathrm{ROM})(\mathrm{p}=.004) \text { and } \\
\text { walking distances } \\
(\mathrm{p}=.043) .\end{array}$ & $\begin{array}{l}\text { society scores (KSS) } \\
\text { were lower in obese } \\
\text { groups than non-obese } \\
\text { groups, statistically } \\
\text { significant in groups A2 } \\
\text { and A3. Preoperative } \\
\text { joint scores were } \\
\text { comparable. At most } \\
\text { recent follow up, no } \\
\text { statistically significant } \\
\text { difference in obese } \\
\text { groups compared to } \\
\text { control, and no statistical } \\
\text { difference in absolute } \\
\text { improvement in scores. }\end{array}$ & $\begin{array}{l}\text { postoperative knee score } \\
\text { (KSS) was significantly } \\
\text { better compared to } \\
\text { preoperative scores } \\
\text { (p=.001). Morbidly obese } \\
\text { patients may achieve } \\
\text { similar pain relief, ROM, } \\
\text { and stability, but are } \\
\text { likely to remain more } \\
\text { functionally impaired } \\
\text { with limitations on } \\
\text { walking distance, } \\
\text { climbing stairs, and a } \\
\text { dependence on a walking } \\
\text { aid. }\end{array}$ & $\begin{array}{l}\text { median weight change } \\
\text { between obese and } \\
\text { non-obese groups at } 12 \\
\text { months. Median IKS } \\
\text { score improved in all } \\
\text { groups at } 12 \text { months. } \\
\text { The change in } \\
\text { functional score was } \\
\text { poorer in both obese } \\
\text { groups, but not } \\
\text { significant. } \\
\text { morbidly obese group } \\
\text { also had a lower score } \\
\text { for pain than the obese } \\
\text { and non-obese group } \\
\text { (p=.021). }\end{array}$ \\
\hline $\begin{array}{l}\text { Implant } \\
\text { Duration }\end{array}$ & $\begin{array}{l}\text { At } 15 \text { years there was a } \\
\text { trend of loosening in } \\
\text { obese patients, but not } \\
\text { statistically significant. }\end{array}$ & $\begin{array}{l}4.9 \% \text { revision rate in } \\
\text { obese group and } 3.1 \% \text { in } \\
\text { non-obese group, but not } \\
\text { significant. Statistically } \\
\text { similar survival rates for } \\
\text { up until } 10 \text { years. }\end{array}$ & $\begin{array}{l}\text { Using solely revision as } \\
\text { an endpoint, the five-year } \\
\text { survivorship was } 74.2 \% \\
\text { and } 100 \% \text { for morbidly } \\
\text { obese and non-obese } \\
\text { groups respectively } \\
\text { ( } \mathrm{p}=.01 \text { ). Using revision } \\
\text { and pain as the endpoint } \\
\text { the survivorship was } \\
72.3 \% \text { and } 97.6 \% \text { in the } \\
\text { morbidly obese and non- } \\
\text { obese groups respectively } \\
\text { ( } \mathrm{p}=.02 \text { ). }\end{array}$ & $\begin{array}{l}\text { Association between } \\
\text { obesity and earlier } \\
\text { prosthetic failure in } \\
\text { primary TKR. }\end{array}$ \\
\hline Discussion & $\begin{array}{l}\text { More patients needing } \\
\text { total knee replacements } \\
\text { are obese. Obesity is } \\
\text { associated with weak } \\
\text { range of motion. } \\
\text { Significant differences } \\
\text { for functional results } \\
\text { were found between the } \\
\text { two groups Obese } \\
\text { patients experienced } \\
32 \% \text { complications, } \\
\text { while non-obese } \\
\text { experienced none. } \\
\text { Moderate obesity yields } \\
\text { nearly same clinical } \\
\text { results as non-obese } \\
\text { patients. At a mean of } 4.8 \\
\text { years, obese patients had } \\
\text { significantly lower knee } \\
\text { and functional scores } \\
\text { compared to the control } \\
\text { group. }\end{array}$ & $\begin{array}{l}\text { Differentiation between } \\
\text { body weight and obesity } \\
\text { because one is an } \\
\text { absolute measure } \\
\text { whereas the other is } \\
\text { relative. Body weight } \\
\text { may be predictive of } \\
\text { increased failure, } \\
\text { whereas BMI may not. } \\
\text { High BMI can stress } \\
\text { cement-bone interface } \\
\text { and potentially lead to } \\
\text { mechanical loosening. } \\
\text { Positive correlation } \\
\text { between wear damage } \\
\text { seen on components and } \\
\text { body weight. No } \\
\text { correlation between } \\
\text { obesity and loosening } \\
\text { rates. KSS for two } \\
\text { groups were comparable. } \\
\text { Presence of } \\
\text { radiolucencies has } \\
\text { positive, significant } \\
\text { correlation with body } \\
\text { weight. No significant } \\
\text { difference in clinical } \\
\text { results at } 7 \text { years follow }\end{array}$ & $\begin{array}{l}\text { TKR is associated with } \\
\text { inferior clinical outcome } \\
\text { scores, higher rate of } \\
\text { complication, and inferior } \\
\text { five-year survivorship } \\
\text { when comparing a } \\
\text { morbidly obese group to a } \\
\text { matched non-obese } \\
\text { group. Influence of BMI } \\
\text { on eventual outcomes of } \\
\text { TKR remains uncertain. } \\
\text { Morbidly obese patients } \\
\text { consistently show worse } \\
\text { results when compared to } \\
\text { obese and non-obese } \\
\text { patients. Increased body } \\
\text { weight results in } \\
\text { increased loading across } \\
\text { the TKR and surrounding } \\
\text { bone, but this does not } \\
\text { lead to higher rates of } \\
\text { failure because obese } \\
\text { patients have lower } \\
\text { activity levels. In } \\
\text { morbidly obese patients, } \\
\text { lower activity levels do } \\
\text { not compensate for } \\
\text { increased stress, which is }\end{array}$ & $\begin{array}{l}\text { Obese patients who } \\
\text { underwent surgery } \\
\text { were a mean of } 4 \text { years } \\
\text { younger and the } \\
\text { morbidly obese } \\
\text { patients were a mean } \\
\text { of } 6 \text { years younger. } \\
\text { Obese and morbidly } \\
\text { obese patients had } \\
\text { poorer functional } \\
\text { results than did non- } \\
\text { obese patients. Poorer } \\
\text { outcome has been } \\
\text { reported for obese } \\
\text { patients and to a } \\
\text { greater degree } \\
\text { morbidly obese } \\
\text { patients. Poorer pain } \\
\text { score may contribute } \\
\text { to the poorer } \\
\text { functionality scores } \\
\text { reported by the obese } \\
\text { and morbidly obese } \\
\text { groups. } \\
\text { morbidly While } \\
\text { patients had lower } \\
\text { QoL scores, their net } \\
\text { change in QoL scores }\end{array}$ \\
\hline
\end{tabular}




\begin{tabular}{|c|c|c|c|c|}
\hline & & $\begin{array}{l}\text { up. At } 33 \text { months, } \\
\text { outcome in morbidly } \\
\text { obese patients was } \\
\text { poorer than other groups. } \\
\text { At } 5 \text { years, significant } \\
\text { difference between } \\
\text { morbidly obese patients } \\
\text { and control groups. } \\
\text { Survivorship rates } \\
\text { statistically significant at } \\
6.2 \text { years. Higher BMI } \\
\text { associated with lower } \\
\text { activity level. }\end{array}$ & $\begin{array}{l}\text { why more radiolucent } \\
\text { lines and loosening were } \\
\text { observed in morbidly } \\
\text { obese patients in this } \\
\text { study. }\end{array}$ & $\begin{array}{l}\text { were the same as the } \\
\text { other groups, so a TKR } \\
\text { is just as beneficial to } \\
\text { morbidly obese } \\
\text { patients. } \\
\text { Complications were } \\
\text { significantly higher in } \\
\text { obese and morbidly } \\
\text { obese patients. For } \\
\text { each unit increase in } \\
\text { BMI, there was an } 8 \% \\
\text { increase in risk of } \\
\text { complication. }\end{array}$ \\
\hline Limitations & $\begin{array}{l}\text { Small number of patients } \\
(\mathrm{n}=100) \text { and short } \\
\text { follow-up period }(3 \\
\text { months). Preoperative } \\
\text { ROM not available from } \\
\text { all patients. }\end{array}$ & $\begin{array}{l}\text { Lack of correlation } \\
\text { between results and } \\
\text { activity level. }\end{array}$ & $\begin{array}{l}\text { When matching patients } \\
\text { based on preoperative } \\
\text { knee score, it was not } \\
\text { always possible to find an } \\
\text { exact match, so the } \\
\text { protocol was to find a } \\
\text { control match with } \\
\text { similar or worse } \\
\text { preoperative score } \\
\text { compared to the morbidly } \\
\text { obese patient. Morbidly } \\
\text { obese patients } \\
\text { represented only a small } \\
\text { proportion of patients } \\
\text { selected for TKR during } \\
\text { the time period of the } \\
\text { study (1995-2004). }\end{array}$ & $\begin{array}{l}\text { Level of follow-up } \\
\text { (some studies exclude } \\
\text { up to } 75 \% \text { of patients } \\
\text { due to lack of follow- } \\
\text { up data; these are } \\
\text { typically the patients } \\
\text { with the poorer } \\
\text { outcomes that are more } \\
\text { dissatisfied). }\end{array}$ \\
\hline Conclusion & $\begin{array}{l}\text { Obese patients } \\
\text { experienced more } \\
\text { complications during the } \\
\text { follow-up period and } \\
\text { their short-term } \\
\text { functionality was } \\
\text { impaired relative to the } \\
\text { control group. Obese } \\
\text { patients should be } \\
\text { informed about their } \\
\text { increased risk of } \\
\text { complication and should } \\
\text { be encouraged to lose } \\
\text { weight prior to their } \\
\text { operation. }\end{array}$ & $\begin{array}{l}\text { Revision and } \\
\text { survivorship rates of } \\
\text { obese patients over the } \\
\text { first decade are } \\
\text { comparable to none- } \\
\text { obese controls. }\end{array}$ & $\begin{array}{l}\text { Present evidence suggests } \\
\text { that patients with a BMI } \\
\text { between } 30 \text { and } 40 \text { have } \\
\text { comparable results to } \\
\text { non-obese patients, but } \\
\text { results are inferior when } \\
\text { compared to the non- } \\
\text { obese patients if the BMI } \\
\text { exceeds } 40 \text {. These } \\
\text { patients should lose } \\
\text { weight prior to surgery or } \\
\text { be counseled about their } \\
\text { inferior results before } \\
\text { proceeding with the } \\
\text { surgery. }\end{array}$ & $\begin{array}{l}\text { Obese patients should } \\
\text { be counseled about the } \\
\text { poorer functional } \\
\text { outcome after TKR as } \\
\text { well as the increased } \\
\text { risk of complication. } \\
\text { The eligibility of } \\
\text { morbidly obese } \\
\text { patients to receive a } \\
\text { TKR warrants further } \\
\text { consideration. }\end{array}$ \\
\hline
\end{tabular}

implant survivorship. The four studies all had a purpose along the lines of this: to determine the impact of obesity on the outcome of total knee arthroplasties. The methods of each study varied greatly, but in all studies there were at least two groups. One control group consisting of non-obese patients, and at least one second group consisting of obese or morbidly obese patients. A wide range of tests was used to determine functionality gained from surgery. Spicer, D. D. M., et al. (2001) and Dowsey, M. M., et al. (2010) noted a trend in early age of total knee arthroplasties in obese and morbidly obese patients, while Jarvenpaa, J., et al. (2010) and Amin, A. K., et al. (2006) noted there was not a significant difference in age.

For the perioperative and immediate results Jarvenpaa, J., et al. (2010), Amin, A. K., et al. (2006), and Dowsey, M. M., et al. (2010) all noted a higher rate of complication in obese and morbidly obese patients. In addition to this, Spicer, D. D. M., et al. (2001) and Amin, A. K., et al. (2006) had more radiolucent lines or radiographic wear in obese or morbidly obese patients, which can be signs of early loosening of the prosthetic. For the functional outcomes, of the studies that did find differences, Jarvenpaa, J., et al. (2010) and Amin, A. K., et al. (2006) found limitations with walking distances in obese and morbidly obese patients. Jarvenpaa, J., et al. (2010) found that range of motion was impaired by obesity while Amin, A. K., et al. (2006) contradicted that. Dowsey, M. M., et al. (2010) found morbidly obese patients had more pain while Amin, A. K., et al. (2006) contradicted that. 
Finally, Spicer, D. D. M., et al. (2001) and Dowsey, M. M., et al. (2010) found no significant improvement in knee functionality scores. Lastly for the survival rates of the implants, Jarvenpaa, J., et al. (2010) and Spicer, D. D. M., et al. (2001) found that there was increased long-run implant failure with obesity but it was not statistically significant; however, Dowsey, M. M., et al. (2010) associated obesity with increased implant failure. Amin, A. K., et al. (2006) found significantly decreased survival rates in obese patients after five years.

The discussions of all four studies did definitively associate morbid obesity with worse clinical outcomes. The studies did not come to a consensus on the outcome of obese patients. All four of the studies were subjected to their own limitations, none of which overlapped. As for the final remarks, Jarvenpaa, J., et al. (2010), Amin, A. K., et al. (2006), and Dowsey, M. M., et al. (2010) said that obese patients should be counseled about weight loss or encourage to lose weight prior to surgery. Spicer, D. D. M., et al. (2001) insinuated that obesity takes minimal effect on TKA outcome.

\section{Discussion}

Obesity is an epidemic on the rise in America. This is a rapidly growing group of people, and a growing percentage of them will end up needing their knees replaced. Since many surgeons refuse to do total knee replacements in obese patients, they are out of luck. They are turned away and told they need to lose weight, but their excruciating knee pain prevents them from doing so. Without clear literature to either justify or deter surgeons from performing this operation in obese and morbidly obese patients, it leaves surgeons up to taking chances, and in medicine that might be an unforgiving risk. This research just contributes to the pile of other studies that could not draw a strong conclusion, but it is different in that it wants a definite answer.

While this study was very limited because it only looked at four studies, it was able to emphasize how little consensus there is on this topic and how overlooked it is. There were multiple instances in this study's analysis process in which one study drew a conclusion and another study was able to confidently contradict that. Studies looking into outcomes of total knee replacements need to be standardized and unbiased, so this does not happen. Contradictory studies like the ones aforementioned are helpful in that they are pointing out the flaws of current research around this topic, but they do not help to advance the research of this topic.

Some of the discussions and conclusions of the studies looked at brought up valid points, such as Spicer, D. D. M., et al. (2001), which noted that the differentiation between body weight and obesity is important because one is an absolute measure whereas the other is relative. Body weight may be predictive of increased failure, whereas BMI may not. If this were to be the case, then most studies are approaching the problem from the wrong angle, including this study. Perhaps studies looking strictly at body weight rather than body mass index could draw conclusions that would be agreed upon and could ignite a change in the total knee replacement procedure and implant. Unfortunately, until something changes, conclusions of these types of studies will continue to read something similar to this: "Obese patients should be counseled on their increased risk and encouraged to lose weight prior to surgery."

\section{Research Methods and Data Collection}

The style of data collection used was a meta-analysis. Six studies were found on Google Scholar using the following keywords or phrases: "total knee arthroplasty," "effect," "obesity," and "outcome." After a preliminary reading, the four studies that closest fit the research question moved on and were further analyzed. Each study was read through multiples times, annotated, and summarized. Following this, a more in-depth analysis looked specifically at these eight features: purpose, methods, perioperative and immediate results, implant survival results, functionality results, discussion, limitations, and conclusions. Information from each study was entered into a chart where cross-examination of the certain criteria for each study could be observed and conclusions could be drawn, as shown in Table 1. Similarities and differences were noted and analyzed.

\section{Acknowledgments}

Thank you to Mount Hebron High School for offering the Intern/Mentor class which allowed for this research to be possible and to Dr. Kiehl and Dr. Mess for overseeing this research.

\section{References}

Amin, A. K., Clayton, R. A. E., Patton, J. T., Gaston, M., Cook, R. E., \& Brenkel I. J. (2006). Total knee replacement in morbidly obese patients. The Journal of Bone and Joint Surgery, 88, 1321-1326. Doi:10.1302/0301-620X.88B10.17697

Amin, A. K., Patton, J. T., Cook, R. E., \& Brenkel, I. J. (2006). Does obesity influence the clinical outcome at five years following total knee replacement for osteoarthritis? Bone \& Joint Journal, 88, 335-340. https://doi.org/10.1302/0301-620X.88B3.16488.

Craik, J.D., Bircher, M.D., \& Rickman, M. (2016). Hip and knee arthroplasty implants contraindicated in obesity. Annals of the Royal College of Surgeons of England, 98, 295-299. doi 10.1308/rcsann.2016.0103

Dowsey, M. M., Liew, D., Stoney, J. D., \& Choong, P. F. (2010). The impact of pre-operative obesity on weight change and outcome in total knee replacement. The Journal of Bone and Joint Surgery, 92, 513-520. Doi:10.1302/0301-620X.92B4.23174

Foran, J.R., Mont, M.A., Etienne, G., Jones, L.C., \& Hungerford, D.S. (2004). The outcome of total knee arthroplasty in obese patients. The Journal of Bone and Joint Surgery, 86, 1609-1615.

Frey, R. (2015). Knee Replacement. The Gale Encyclopedia of Medicine, Vol. 5, 2878-2886. 
Retrieved from

http://go.galegroup.com/ps/i.do?p=GVRL\&sw=w\&u=hcpub_hebron\&v=2.1\&it=r\&id=GALE\%7CCX3623301054\&asi $\mathrm{d}=114 \mathrm{~d} 7 \mathrm{c0fca} 7 \mathrm{bfd0da2234edcd7e27bf9}$

Jarvenpaa, J., Kettunen, J., Kroger, H., \& Miettinen, H. (2010). Obesity may impair the early outcome of total knee arthroplasty. Scandinavian Journal of Surgery, 99, 45-49. DOI: $10.1177 / 145749691009900110$

Rodriguez-Merchan, E.C. (2014). The influence of obesity on the outcome of TKR: can the impact of obesity be justified from the viewpoint of the overall health care system. The Musculoskeletal Journal of Hospital for Special Surgery, 10, 167-170. DOI: 10.1007/s11420-014-9385-9

Salih, S. \& Sutton, P. (2013). Obesity, knee osteoarthritis and knee arthroplasty: a review. BMC Sports Science, Medicine and Rehabilitation, 5. doi:10.1186/2052-1847-5-25

Spicer, D. D. M., Pomeroy, D. L., Badenhausen, W. E., Schaper, L. A., Curry, J. I., Suthers, K.

E., \& Smith, M. W. (2001). Body mass index as a predictor of outcome in total knee replacement. International Orthopaedics, 25, 246-249. DOI:10.1007/s002640100255

Stevens-Lapsley, J.E., Peterson, S.C., Mizner, R.L., \& Snyder-Mackler, L. (2009). The impact of body mass index on functional performance after total knee arthroplasty. The Journal of Arthroplasty, 7, 1104-1109. doi:10.1016/j.arth.2009.08.009.

Vaishya, R., Vijay, V., Wamae, D., \& Agarwal, A.K. (2016). Is total knee replacement justified in morbidly obese? A systematic review. Cureus Journal of Medical Science, 8. Doi: 10.7759/cureus.804

Wang, C., Guo, Y., Shi, J., \& Chen, W. (2017). A numerical investigation into the effects of overweight and obesity on total knee arthroplasty. Journal of Healthcare Engineering, 2017. doi:10.1155/2017/149637 